\title{
Pengembangan Media Pembelajaran PAUD melalui PPG
}

\author{
Oktarina Dwi Handayani ${ }^{\otimes_{1}}$ \\ Pendidikan Guru Pendidikan Anak Usia Dini, Universitas Muhammadiyah Prof. Dr. Hamka \\ DOI: $\underline{10.31004 / o b s e s i . v 5 i 1.522}$
}

\begin{abstract}
Abstrak
Pendidikan profesi guru (PPG) merupakan pendidikan yang diperuntukkan bagi pendidik Pendidikan Anak Usia Dini (PAUD) dalam upaya pengembangan kompetensi. Melalui PPG pendidik diberikan keterampilan dalam mengelola kegiatan pembelajaran dimulai dari tahapan perencanaan hingga evaluasi pembelajaran. Salah satu keterampilan yang dikembangkan melalui PPG adalah dalam pengembangan media pembelajaran, yaitu merancang, menggunakan dan membuat media pembelajaran dari bahan-bahan yang ada dilingkungan sekitar. Penelitian ini bertujuan untuk memberikan gambaran mengenai persepsi mahasiswa terhadap pelaksanaan PPG dalam pengembangan media pembelajaran PAUD. Penelitian ini menggunakan metode kuantitatif dengan menggunakan uji regresi linear sederhana. Berdasarkan penelitian yang telah dilaksanakan didapatkan hasil bahwa setiap penambahan nilai persepsi mahasiswa menyebabkan penambahan pada nilai pengembangan media pembelajaran jadi dapat disimpulkan bahwa variabel persepsi mahasiswa pada pelaksanaan PPG berpengaruh terhadap variabel kemampuan pengembangan media pembelajaran PAUD.
\end{abstract}

Kata Kunci: media pembelajaran, pendidikan profesi guru, anak usia dini

\begin{abstract}
Teacher professional education (PPG) is an education intended for educators Early Childhood Education (ECE) in developing competency. Through PPG educators are given skills in managing learning activities starting from the planning stage to the evaluation of learning. One of the skills developed through PPG is in the development of instructional media, namely designing, using and making learning media from materials that are in the surrounding environment. This study aims to provide an overview of students' perceptions of the implementation of PPG in the development of ECD learning media. This research uses quantitative methods using a simple linear regression test. From the research that has been carried out, the results show that for each addition of $1 \%$ the value of students' perceptions, the value of developing instructional media increases by 0.835 . Based on the results of statistical data analysis, it is known that the $t$ value of $8.906>t$ table 1.99834 concluded that the student perception variable on the implementation of PPG has an effect on the ability to develop PAUD learning media.
\end{abstract}

Keywords: learning Media; teacher professional education; early childhood

Copyright (c) 2020 Oktarina Dwi Handayani

$\triangle$ Corresponding author :

Email Address : oktarina2h@uhamka.ac.id (Jalan tanah merdeka No.6 Pasar Rebo, Jakarta Timur)

Received 20 April 2020, Accepted 8 May 2020, Published 9 May 2020 


\section{PENDAHULUAN}

Pendidikan Anak Usia Dini (PAUD) merupakan pendidikan yang berfungsi sebagai stimulasi awal bagi anak usia 0-6 tahun (Kementerian Pendidikan dan Kebudayaan, 2003). Pendidikan ana usia dini berperan sebagai pondasi awal dalam stimulasi aspek perkembangan anak yang meliputi aspek sosial emosional, kognitif, fisik motorik, moral spiritual serta bahasa. Kegiatan pembelajaran PAUD dilaksanakan melalui kegiatan bermain sambil belajar, diartikan sebagai anak diberi kegiatan main yang mengandung nilai edukasi yang bertujuan menstimulasi aspek perkembangan anak. Untuk itulah seorang pendidik harus memiliki 4 kompetensi seperti yang tertuang dalam peraturan menteri pendidikan no.16 tahun 2007 tentang standart kualifikasi akademik dan standar kompetensi guru. Dalam peraturan tersebut dijelaskan bahwa seorang pendidik harus memiliki kualifikasi akademik sesuai dengan bidang keilmuan yang diembannya serta standart kompetensi meliputi kompetensi; pedagogik, kepribadian, sosial, dan professional, keempat kompetensi tersebut terintegrasi meliputi kompetensi; pedagogik, kepribadian, sosial, dan professional, keempat kompetensi tersebut terintegrasi dalam kinerja pendidik (Prof. Dr. Sudarwan Danim, 2015).

Kompetensi sosial diartikan bahwa seorang pendidik harus memiliki kemampuan untuk beradpatasi dengan lingkungannya baik dengan teman sejawat, peserta didik maupun dengan wali murid. Kompetensi pedagogik memiliki pengertian bahwa seorang pendidik harus memiliki kemampuan dalam pendidikan, pengajaran, pembelajaran serta pembimbing pada anak usia dini sesuai dengan tahapan perkembangannya. Kompetensi kepribadian seorang pendidik diartikan seorang pendidik harus berperilaku sesuai dengan norma, adat, budaya serta agama sehingga dapat menampilkan kepribadian yang berbudi pekerti luhur. Kompetensi profesional pendidik PAUD mengandung makna bahwa seorang pendidik PAUD harus memiliki pemahaman terkait dengan pertumbuhan dan perkembangan anak serta membangun koneksi bersama dengan wali murid dalam rangka pendidikan, perlindungan dan pengasuhan anak didalam keluarga (Christianti, 2015). Oleh karena itu PAUD merupakan salah satu lembaga pendidikan yang memiliki arti penting dalam mengantarkan anak menuju jenjang pendidikan selanjutnya sehingga pendidik PAUD harus profesional dalam melaksanakan tugasnya.

Kompetensi pendidik PAUD yang masih rendah merupakan salah satu permasalahan dalam perkembangan PAUD di Indonesia. Berdasarkan data yang dihimpun oleh Kemendikbud tentang data statistik PAUD tahun 2018 disebutkan bahwa pendidik PAUD di Indonesia yang memiliki kualifikasi pendidikan jenjang Strata 1 (S1) sebesar 30,94\% (Pdspk et al., 2017). Dari data tersebut diketahui bahwa sebagian besar pendidik PAUD belum memiliki jenjang pendidikan yang sesuai dengan tugasnya sebagai pendidik yaitu belum memiliki kualifikasi pendidikan S1. Hal ini mempengaruhi kualitas pembelajaran yang dilaksanakan serta berdampak pada kualitas peserta didik yang dibinanya. Permasalahan lain yang dihadapi oleh pendidik PAUD (bukan hanya di Indonesia) adalah meningkatnya beban kerja sebagai dampak reformasi pendidikan, penghasilan guru yang rendah dampak dari minimnya pengakuan profesional pendidik PAUD serta kondisi kerja yang menantang di mana pendidik harus mampu memahami karkateristik peserta didik dengan berbagai latar belakang budaya, sosial dan ekonomi (Wolf, 2018). Pendidik memiliki peran yang penting dalam membangun pemahaman peserta didik agar dapat meraih prestasi dalam bidang akademik (Ries, 2016).

Pendidik yang profesional haruslah memiliki keempat kompetensi yang telah disebutkan di atas agar proses pembelajaran berjalan dengan baik dan benar. Pendidik PAUD dituntut untuk bisa melaksanakan kegiatan pembelajaran sesuai dengan usia dan tahapan perkembangan anak dengan menyajikan kegiatan belajar sembari bermain. Oleh karena itu desain kegiatan belajar yang dibangun melalui kegiatan main bertujuan memberikan kesempatan anak-anak untuk berpartisipasi dalam kegiatan bermain. Melalui beragam proses seperti mendengarkan, diskusi menyalurkan ide dan gagasan (Correia et al., 
2020). Media pembelajaran memiliki peran penting dalam kegiatan pembelajaran PAUD, berfungsi sebagai sarana dalam menyampaikan materi dan pengetahuan yang hendak dibangun melalui kegiatan bermain (Saurina, 2016). Permasalahan yang sering muncul adalah pemahaman pendidik akan pentingnya media pembelajaran belum terbentuk secara maksimal terlihat dari pendidik kurang sesuai mengaplikasikan media pembelajaran dalam proses pembelajaran (Saurina, 2016). Hal tersebut membawa dampak pada kebutuhan anak dalam pembelajaran tidak terpenuhi, sehingga pembelajaran yang dilaksanakan menjadi tidak efektif (Nurhafizah, 2018).

Permasalah lain yang timbul dari pelaksanaan PAUD di Indonesia adalah memiliki model pembelajaran yang berbeda beda yaitu; model sentra, area dan kelompok. Model pembelajaran yang digunakan disesuaikan dengan kemampuan masing-masing lembaga. Berdasarkan hasil pengamatan yang dilaksanakan peneliti dilapangan, pendidik PAUD belum memahami dengan baik aplikasi masing-masing model pembelajaran. Hal ini berdampak pada tidak sesuaian antara rancangan kegiatan main dan pengembangan media pembelajaran. Ketidaksesuai media pembelajaran yang digunakan dapat menghambat kegiatan pembelajaran yaitu tidak munculnya reaksi peserta didik pada kegiatan pembelajaran (Sumarsih \& Mukminan, 2016). Berdasarkan hasil penelitian terdahulu tentang pentingnya pengembangan media pembelajaran pada PAUD dapat membawa dampak bagi pertumbuhan aspek perkembangan anak (Kiromi \& Fauziah, 2016). Berdasarkan deskripsi permasalah tersebut pendidik PAUD membutuhkan kegiatan peningkatan kompetensi agar meningkatkan keterampilan guru dalam merancang media pembelajaran. Peningkatan kompetensi bagi pendidik dilaksanakan melalui pendidikan dan pelatihan hal ini bertujuan agar pendidik memiliki kompetensi yang baik dalam melaksanakan tugas nya dan mampu memberi sumbang saran bagi lembaga tempat bekerja (Nuraeni \& Riyanto, 2017). Kemampuan seorang pendidik dalam menganalisis permasalahan dalam proses pendidikan peserta didik serta menemukan solusi dari permasalahan merupakan salah satu kompetensi profesional yang harus dibangun dan dikuasai.

Berdasarkan identifikasi permasalahan PAUD di atas pemerintah membentuk program yang diwujudkan dalam kegiatan peningkatan kompetensi bagi pendidik PAUD. Salah satunya dilaksanakan melalui PPG yang bertujuan menciptakan calon pendidik yang berkompeten sehingga mampu mencetak generasi penerus bangsa yang beriman dan bertakwa kepada Tuhan Yang Maha Esa, berbudi pekerti luhur, sehat jasmani dan rohani, berpengetahuan, ulet, terampil serta memiliki rasa tanggung jawab (Ningrum, 2016). Melalui PPG pendidik diberi keterampilan dalam pengembangan media pembelajaran (Pangestika \& Alfarisa, 2015). Pelaksanaan PPG pada mata pelajaran PAUD bertujuan dalam peningkatan kompetensi salah satunya dalam hal merancang media pembelajaran. Media pembelajaran merupakan salah satu komponen yang penting dalam pembelajaran PAUD, pengembangan media pembelajaran bertujuan agar pendidik mampu melaksanakan kompetensi pedagogi yang berkualitas sehingga menumbuhkan lingkungan belajar yang menyenangkan pada anak usia dini. (Church \& Bateman, 2019).

Universitas Muhammadiyah Prof Dr Hamka merupakan salah satu penyelenggara PPG pada mata pelajaran PAUD. Kegiatan awal penelitian dilaksanakan melalui observasi yang dilaksanakan peneliti pada program studi PPG PAUD UHAMKA dalam rangka mengambil data lapangan awal. Berdasarkan data hasil observasi awal diketahui bahwa peserta PPG yang berasal dari beberapa provinsi di Indonesia, antara lain Jakarta, Sumatera, Kalimantan, Jawa Tengah dan Yogyakarta memiliki kemampuan yang berbeda dalam kegiatan merancang kegiatan main maupun dalam pengembangan media pembelajaran pada PAUD. Media yang selama ini digunakan oleh para pendidik kurang bervariatif dan sebagian besar masih mempergunakan lembar kerja pada pelaksanaan pembelajarannya. Hal tersebut bertolak belakang dengan prinsip pembelajaran PAUD yaitu kreatif, aktif dan menyenangkan. Oleh karena itu diperlukan bimbingan kepada mahasiswa PPG mengenai pengembangan media pembelajaran agar terciptakan kegiatan pembelajaran yang 
mengedapankan kemampuan anak dalam berpikir tingkat tinggi atau Higher Order Thinking Skill (HOTS). Peserta didik merupakan objek belajar pasif melalui pembelajaran HOTS menjadikan kegiatan belajar yang dilaksanakan peserta didik menjadi aktif. Peserta didik membangun pengetahuan dan pemahamannya melalui berbagai sumber pembelajaran (Usmaedi, 2017). Kemampuan yang hendak dibangun melalui HOTS ini meliputi kemampuan kognitif meliputi kemampuan penalaran, pengembangan logika, melakukan analisa, menciptakan ide, pemecahan masalah masalah serta keterampilan penarikan keputusan (Kurniati et al., 2016). Pengembangan media pembelajaran yang bervariatif bermanfaat bagi anak usia dini dalam menciptakan pengalaman pembelajaran yang nyata (Kustiawan, 2016). Berdasarkan deskripsi diatas maka perlu dilaksanakan kegiatan penelitian dalam rangka melihat persepsi mahasiswa terhadap pengembangan media pembelajaran PAUD melalui PPG di Universitas Muhammadiyah Prof. Dr. Hamka. Dari data hasil penelitian dapat digunakan sebagai masukan dalam pengembangan pelaksanaan PPG kedepan. Tujuan yang hendak dicapai melalui pelaksanaan penelitian ini adalah memberikan gambaran mengenai persepsi mahasiswa terhadap pelaksanaan PPG dalam pengembangan media pembelajaran PAUD.

\section{METODOLOGI}

Penelitian ini dilaksanakan di Universitas Muhammadiyah Prof. Dr.Hamka (UHAMKA) pada program (PPG) dengan mengambil responden mahasiswa PPG PAUD tahap 1 sampai tahap 5 tahun 2019. Kegiatan penelitian ini diawali dengan melakukan studi pendahuluan untuk mendapatkan data lapangan awal. Studi pendahuluan dilakukan dengan observasi dan wawancara pada objek penelitian yaitu pada mahasiswa dan pelaksanaan PPG PG PAUD UHAMKA. Dari studi pendahuluan yang dilaksanakan didapatkan hasil yang digunakan peneliti untuk menyusun analisa permasalahan. Dari analisis permasalahan yang telah didapatkan, peneliti menyusun referensi atau kajian pustaka yang dijadikan dasar dalam penyusunan variabel dan instrumen penelitian. Instrumen yang telah dinyatakan valid siap dijadikan sebagai alat dalam pengumpulan data penelitian. Total sampel sebanyak 65 orang dan seluruhnya berjenis kelamin perempuan. Penelitian ini dilaksanakan guna mengkaji secara ilmiah tentang persepsi mahasiswa mengenai pelaksanaan PPG dalam pengembangan media pembelajaran. Data diambil melalui angket yang disebar melalui google form, hasil angket disajikan dalam bentuk data kuantitatif berisi data-data berupa angka hasil jawaban reponden. Data yang terkumpul dihitung dengan menggunakan analisis data statistik SPSS. Hasil perhitungan data dideskripsikan dengan kalimat deskripstif kualitatif hal ini dimaksudkan untuk mempermudah memahami hasil akhir penelitian. Alur penelitian yang telah dilaksanakan oleh peneliti dapat digambarkan seperti alur dibawah ini; 


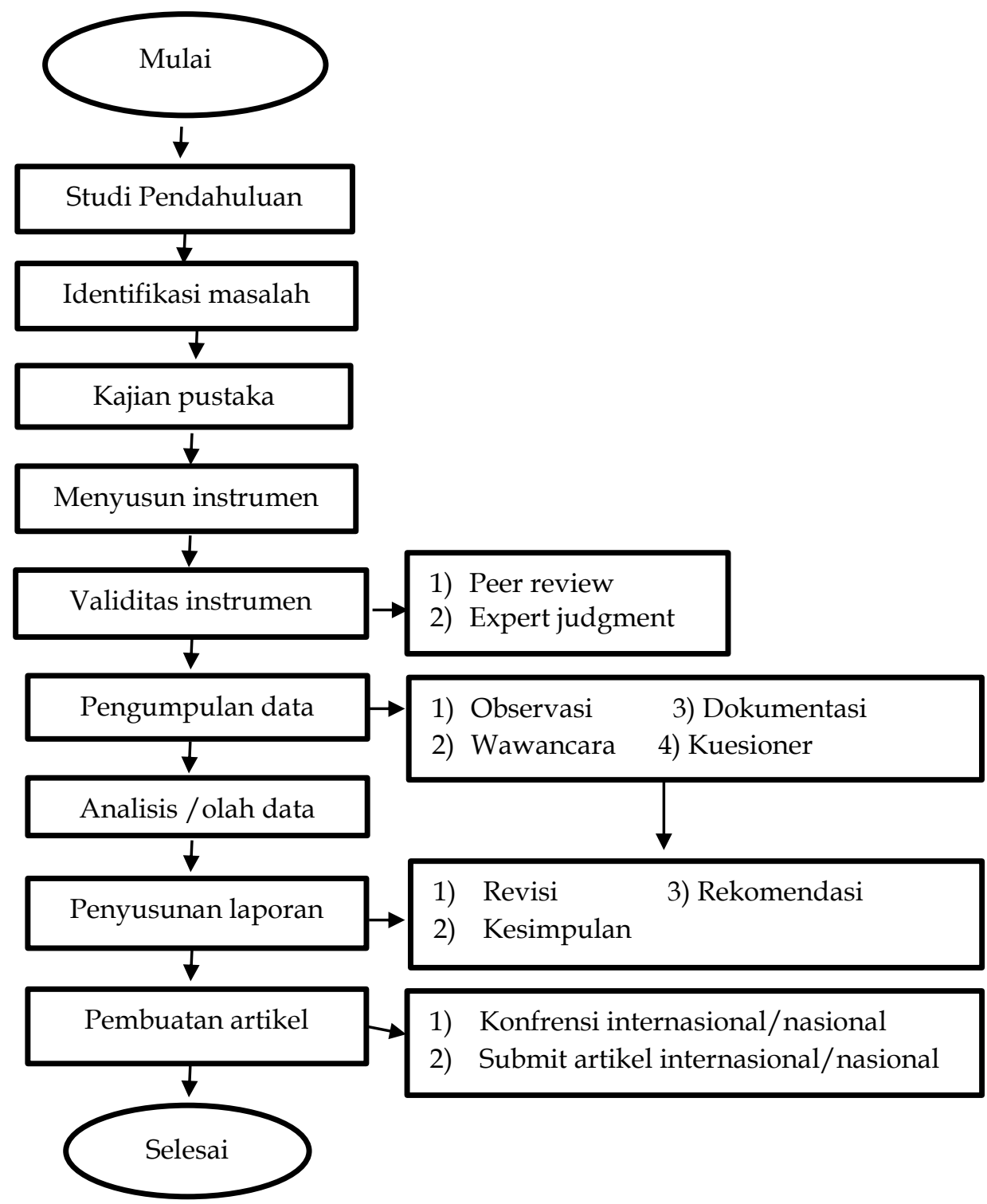

Bagan 1. Alur penelitian

\section{HASIL DAN PEMBAHASAN}

\section{Menganalisa Persepsi Mahasiswa terhadap Pelaksanaan PPG PAUD UHAMKA}

Dari data kuesioner yang dikumpulkan dari mahasiswa PPG PAUD mengenai persepsi mahasiswa terhadap pelaksanaan PPG $(X)$ didapatkan hasil standar deviasi sebesar $(6,847)$ dengan nilai minimum 49 dan maksimum 68. Berdasarkan data tersebut disimpulkan bahwa persepsi mahasiswa terhadap program PPG PAUD adalah sebagai berikut; pernyataan sangat setuju sebesar $44,98 \%$, setuju sebesar $54,48 \%$, tidak setuju sebesar $0,54 \%$ dan tidak setuju sekali sebesar 0,00\%. Berdasarkan kuesioner yang disebarkan kepada mahasiswa PPG didapatkan data bahwa persepsi mahasiswa mengenai program PPG adalah sebagai berikut; (1). sesuai dengan kebutuhan mahasiswa sehingga mampu menunjang pekerjaan sebagai pendidik PAUD, (2) materi yang diberikan mudah dipahami dan sistematis, (3) diberikan secara menarik dan aplikatif, (4) menambah wawasan dalam merancang media pembelajaran, (5) Metode pembelajaran yang digunakan menarik, (6) cara penyampaian materi mudah dipahami, (7) Pembelajaran dilaksanakan tepat waktu, (8) menggunakan alat bantu, bahan ajar yang sesuai dengan materi yang diberikan.

Pelaksanaan program PPG bagi pendidik PAUD yang dilaksanakan di UHAMKA merupakan perwujudan peningkatan kompetensi bagi pendidik PAUD. Pelaksanaan PPG dilaksanakan melalui serangkaian tahapan yaitu : 


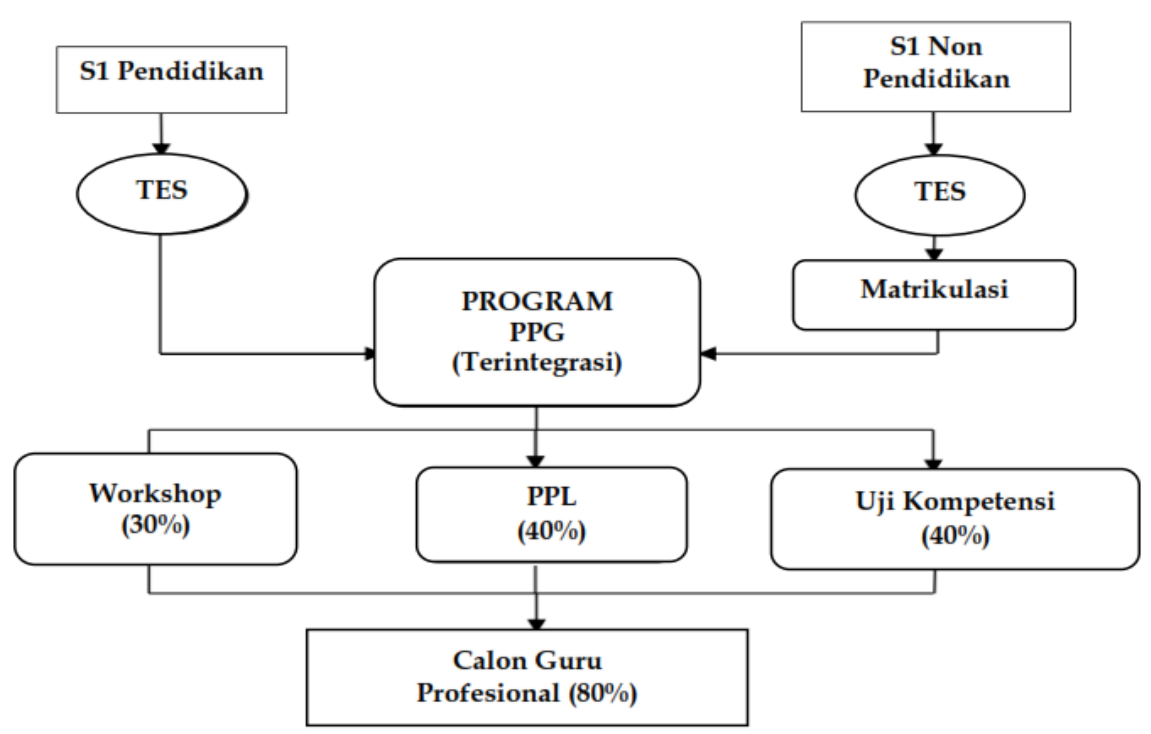

Gambar 2. Model penyelenggaraan PPG (Anik Gufron, 2010)

Kegiatan workshop pada penyelenggaraan PPG PAUD dilaksanakan melalui lokakarya meliputi (1) rancangan kegiatan program tahunan, semester sampai pada rancangan kegiatan harian (2) bahan ajar, (3) media pembelajaran dan (4) penyusunan instrumen penilaian. Kegiatan praktik pengalaman lapangan (PPL) merupakan kegiatan praktik belajar mengajar yang dilaksanakan oleh mahasiswa pada lembaga PAUD yang telah ditunjuk oleh pihak universitas penyelenggara. Tahapan PPL ini meliputi; tahapan observasi bertujuan untuk pengenalan lapangan, kegiatan pengajaran mikro dan makro dalam bentuk pelatihan mengajar terbimbing dan latihan mengajar mandiri (Pangestika \& Alfarisa, 2015). Tahap akhir dari penyelengaraan PPG adalah uji kompetensi yang meliputi ujian tulis dan kinerja. Mahasiswa yang melaksanakan uji kompetensi adalah mahasiswa yang berhasil lulus dari tahap workshop dan PPL. Berdasarkan rangkaian dari tahapan pelaksanaan PPG mahasiswa berpendapat bahwa pelaksanaan PPG merupakan salah satu sarana dalam peningkatan kompetensi dalam merancang media.

\section{Menganalisa Peningkatan kompetensi Pembuatan Media Pembelajaran melalui Pelaksanaan program PPG bagi pendidik PAUD}

Pada variabel peningkatan kompetensi pembuatan media pembelajaran (Y) diperoleh data standart deviasi sebesar 4,156 dengan nilai minimum 25 dan maksimum 50. Dari data yang diambil didapatkan hasil mahasiswa menyatakan sangat setuju sebesar 33,85\%, setuju sebesar $63,59 \%$, tidak setuju sebesar 2,18\% dan tidak setuju sekali sebesar. Data tersebut didapatkan dari kuesioner yang disebarkan kepada mahasiswa PPG didapatkan hasil bahwa; (1) materi pengembangan media pembelajaran membentuk guru memahami materi ajar media pembelajaran, (2) membentuk kompetensi dalam langkah- langkah merancang media pembelajaran, (3) meningkatkan kemampuan mahasiswa dalam merancang pengembangan media pembelajaran dari berbagai bahan yang ada dilingkungan sekitar, (4) membentuk mahasiswa yang memiliki kemampuan dalam mengembangkan media pembelajaran sesuai dengan tahapan perkembangan anak, (5) membentuk mahasiswa memiliki kemampuan dalam mengembangkan media pembelajaran dengan biaya yang efisien, (6) membentuk mahasiswa dalam mengembangkan media pembelajaran yang dapat menstimulasi perekembangan dan kreativitas anak, (7) mahasiswa mampu merancang evaluasi media pembelajaran yang digunakan dalam pembelajaran, (8) membentuk mahasiswa dalam melaksanakan tindak lanjut hasil evaluasi media pembelajaran. 
DOI: 10.31004/obsesi.v5i1.522

\section{Persepsi Mahasiswa dalam Peningkatan Kompetensi Merancangan Media Pembelajaran PAUD melalui Pelaksanaan Pendidikan Profesi Guru (PPG)}

Pengolahan data hasil penelitian dilakukan melalui analisis regresi linear sederhana yang bertujuan untuk memperoleh gambaran hubungan antara variabel persepsi mahasiswa (X) dengan Pengembangan media pembelajaran (Y) melalui pelaksanaan PPG, didapatkan hasil sebagai berikut;

Tabel 1. Analisis Korelasi Pearson

\begin{tabular}{llrr}
\hline & & \multicolumn{1}{c}{$\begin{array}{c}\text { Persepsi } \\
\text { Mahasiswa }\end{array}$} & $\begin{array}{c}\text { Pengembangan media } \\
\text { pembelajaran }\end{array}$ \\
\hline Persepsi & Pearson Correlation & 1 & $.747^{* *}$ \\
Mahasiswa & Sig. (2-tailed) & & .000 \\
& $\mathrm{~N}$ & 65 & 65 \\
Pengembangan & Pearson Correlation & $.747^{* *}$ & 1 \\
media & Sig. (2-tailed) & .000 & 65 \\
pembelajaran & $\mathrm{N}$ & 65 & \\
$* *$ Correlation is significant at the 0.01 level (2-tailed) & & \\
\hline
\end{tabular}

Dari tabel diatas menunjukkan bahwa nilai signifikansi sebesar 0,000 menunjukkan adanya korelasi hubungan antara variabel $X$ dan $Y$ jadi terdapat hubungan antara persepsi mahasiswa pada pelaksanaan PPG terhadap pengembangan media pembelajaran PAUD. nilai korelasi pearson sebesar 0,747 menunjukkan hubungan yang kuat antara variabel persepsi mahasiswa terhadap pengembangan media pembelajaran melalui pelaksanaan PPG PAUD di Universitas Muhammadiyah Prof Dr. Hamka.

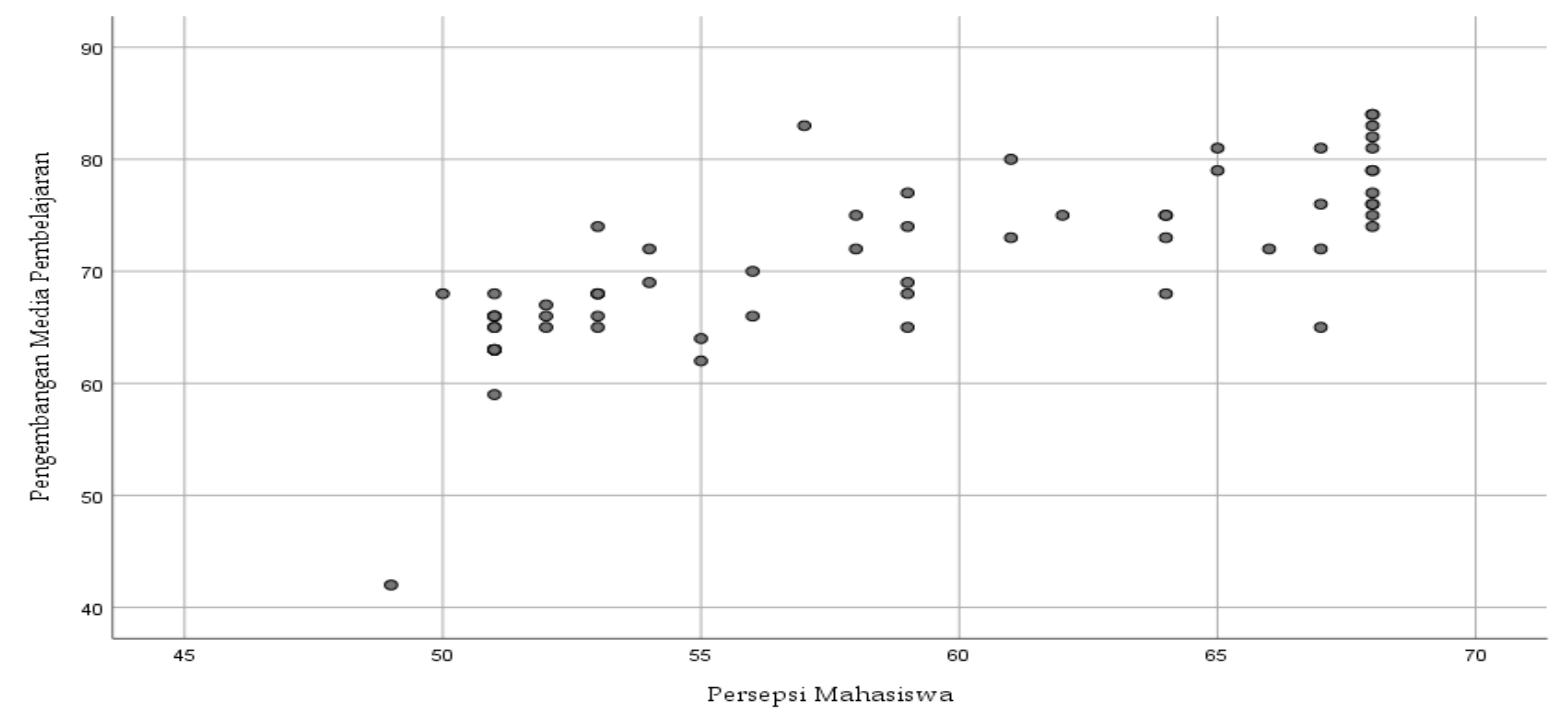

Gambar 4. Scaater ploot dan model linear variabel $\mathrm{X}$ dan $\mathrm{Y}$

Gambar diatas menunjukan bahwa adanya korelasi antara variabel persepsi mahasiswa $(X)$ dengan pengembangan media pembelajaran $(Y)$ bersifat positif, artinya terdapat kecenderungan bahwa semakin besar harga variabel $\mathrm{X}$ akan diikuti oleh variabel $\mathrm{Y}$. sehingga persamaan regresinya dapat ditulis;

$$
\begin{aligned}
& Y=a+b X \\
& Y=13.173+0.453
\end{aligned}
$$


Berdasarkan hasil perhitungan diperoleh konstan (a) adalah 13,173 sedang nilai trust (B) adalah 0,453 persamaan tersebut dapat diartikan bahwa perubahan bersifat $(+)$ jadi setiap penambahan $1 \%$ nilai persepsi mahasiswa maka nilai pengembangan media pembelajaran bertambah sebesar 0,835 . Koefisien regresi tersebut bernilai positif sehingga dapat dikatakan bahwa pengaruh variabel $\mathrm{X}$ terhadap $\mathrm{Y}$ adalah bernilai positif. Berdasarkan data diatas maka dapat disimpulkan pengambilan keputusan dalam uji linear sederhana diperoleh nilai signifikansi sebesar $0,000<0.005$ sehingga dapat disimpulkan bahwa variabel $X$ berpengaruh terhadap variabel Y. Berdasarkan nilai diketahui nilai $t$ hitung sebesar $8.906>t$ babel 1.99834 sehingga dapat disimpulkan bahwa variabel $X$ berpengaruh terhadap variabel Y.

Media pembelajaran merupakan salah satu kunci dalam pembelajaran anak usia dini. Media merupakan sarana dalam menyampaikan pesan dari pendidik kepada peserta didiknya. Kegiatan pembelajaran yang ditunjang dengan pengembangan media pembelajaran yang menarik dan aplikatif membawa dampak dalam memaksimalkan hasil perkembangan anak (Gianina-Ana, 2013). Hal ini sejalan dengan penelitian yang dilakukan oleh Saurina tentang pengembangan media pembelajaran untuk anak usia dini menggunakan augmented reality, bahwa pengembangan media pembelajaran perlu dilakukan oleh pendidik agar peserta didik tidak merasa bosan dalam mengikuti kegiatan pembelajaran. Pengembangan media pembelajaran perlu dilakukan agar mengoptimalkan alat indra yang diguakan oleh peserta didik sehingga semakin besar kemungkinan peserta didik memahami materi yang disampaikan oleh pendidik (Saurina, 2016).

Pelaksanaan pengembangan media pembelajaran pada PPG PAUD bertujuan agar mahasiswa memiliki kemampuan untuk mengembangan media pembelajaran pada anak usia dini agar dapat menstimulasi kemampuan kognitif anak dalam hal analisis penalaran, pengembangan logika, melakukan analisa, menciptakan ide, pemecahan masalah masalah serta keterampilan penarikan keputusan. Hal ini sejalan dengan pendapat Widayati dalam penelitiannya tentang; Pengembangan Media Pembelajaran Tutor PAUD Dalam Menggali Perilaku Kerjasama Anak Usia Dini Melalui Gerak Dan Lagu dinyatakan bahwa penggunaan media yang tepat membantu pendidik dalam upaya peningkatan kualitas pembelajaran serta hasil belajar bagi peserta didik. Melalui pengembangan media pembelajaran merupakan salah satu sarana bagi pendidik dalam meningkatkan pengetahuan dan keterampilan dalam rangka peningkatan kompetensinya (Widayati, 2009).

Berdasar hasil pengamatan awal didapatkan data bahwa kemampuan awal yang dimiliki mahasiswa PPG PAUD UHAMKA dalam pengembangan media pembelajaran masih rendah, terlihat dari pelaksanaan workshop mahasiswa belum memahami kesesuaian antara tema yang diambil dengan media pembelajaran yang digunakan. Pengembangan media pembelajaran tiap daerah berbeda disesuaikan dengan kondisi masing-masing lembaga mahasiswa PPG. Misalkan mengambil contoh mahasiswa yang berasal dari Bangka dan Jakarta tentunya akan berbeda dalam pengembangannya, karena kehidupan masyarakat bangka dengan perairan atau laut maka tema yang diambil berkait dengan hasil laut, olahan hasil laut serta transportasi yang diperkenalkan adalah transportasi air. Berbeda dengan mahasiswa PPG yang berasal dari Jakarta pengembangan media pembelajaran yang diperkenalkan ketika mengambil tema transportasi adalah transportasi darat dan udara. Dalam pengembangan media pembelajaran tentunya berbeda dengan pengembangan media pembelajaran mahasiswa PPG yang berasal dari Bangka. Berdasarkan data diatas maka terdeskripsikan bahwa PPG membawa dampak positif pada peningkatan kompetensi mahasiswa dalam kegiatan pengembangan media pembelajaran. Oleh karena itu mahasiswa memiliki persepsi postif terhadap pelaksanaan PPG.

Bentuk peningkatan kompetensi dalam pengembangan media pembelajaran adalah mahasiswa mampu mengembangan media pembelajaran sesuai dengan tema yang diambil. Wujud pengembangan media pembelajaran lainnya adalah mahasiswa mampu mempergunakan alat dan bahan yang ada di lingkungan sekitar atau mempergunakan alat 
permainan edukatif by design. Melalui capaian peningkatan kompetensi yang diperoleh mahasiswa PPG PAUD diharapkan mampu menunjang kompetensinya sebagai seorang pendidik PAUD. Sehingga proses pembelajaran yang dilaksanakan pada peserta didik dalam menyajikan pengalaman langsung yang bersifat nyata, memberikan motivasi serta memunculkan ide, gagasan maupun minat belajar pada anak (Liyana \& Kurniawan, 2019). Media pembelajaran yang digunakan oleh pendidik PAUD hendaknya disesuaikan dengan usia dan tahapan perkembangan anak, memperhatikan faktor keamanan dan kenyamanan anak dalam penggunaanya serta pendidik mudah dalam mengakses alat dan bahan yang digunakan (Zaini \& Dewi, 2017). Untuk memudahkan pendidik mengakses media pembelajaran, maka media pembelajaran idealnya dari barang barang yang ada di lingkungan sekitar.

\section{SIMPULAN}

Pelaksanaan PPG membawa dampak positif bagi pengembangan kemampuan dalam mengembangkan media pembelajaran PAUD. Bentuk pengembangan media pembelajaran yang dilaksanakan pada kegiatan PPG meliputi perencanaan, pembuatan, pengaplikasian dan evaluasi media pembelajaran yang dibuat disesuaikan dengan tema dan usia perkembangan anak serta pembuatan media pembelajaran dengan memanfaatkan bahan yang ada di lingkungan sekitar.

\section{UCAPAN TERIMAKASIH}

Puji syukur kehadirat Alloh SWT yang telah memberikan rahmatNYA sehingga penulis dapat melaksanakan dan menyelesaikan kegiatan penelitian ini. Terimakasih kepada Universitas Muhammadiyah Prof. Dr. Hamka melalui lembaga penelitian dan pengembangan (Lemlit) serta program studi PPG UHAMKA yang telah memberikan fasilitas dan dukungan dalam melaksanakan kegiatan penelitian. Ucapan terima kasih penulis sampaikan kepada tim editor Jurnal Obsesi yang telah memberikan kesempatan, saran, kritik, dan rekomendasi untuk perbaikan artikel ini.

\section{DAFTAR PUSTAKA}

Christianti, M. (2015). Profesionalisme Pendidik Anak Usia Dini. Jurnal Pendidikan Anak, 1(1). https://doi.org/10.21831/jpa.v1i1.2923

Church, A., \& Bateman, A. (2019). Methodology and professional development: Conversation Analytic Role-play Method (CARM) for early childhood education. Journal of Pragmatics, 143, 242-254. https:// doi.org/10.1016/j.pragma.2019.01.022

Correia, N., Carvalho, H., Durães, J., \& Aguiar, C. (2020). Teachers' ideas about children's participation within Portuguese early childhood education settings. Children and Youth Services Review, 111, 104845. https://doi.org/10.1016/j.childyouth.2020.104845

Gianina-Ana, M. (2013). Kindergarten Teachers' Perceptions on in-service Training and Impact on Classroom Practice. Procedia - Social and Behavioral Sciences, 76, 481-485. https://doi.org/10.1016/j.sbspro.2013.04.150

Kementerian Pendidikan dan Kebudayaan. (2003). UU No. 20 Tahun 2003 Tentang Sistem Pendidikan Nasional. http://simkeu.kemdikbud.go.id/index.php/peraturan1/8-uuundang-undang/12-uu-no-20-tahun-2003-tentang-sistem-pendidikan-nasional

Kiromi, I. H., \& Fauziah, P. Y. (2016). Pengembangan media pembelajaran big book untuk pembentukan karakter anak usia dini. Jurnal Pendidikan Dan Pemberdayaan Masyarakat, 3(1), 48. https://doi.org/10.21831/jppm.v3i1.5594

Kurniati, D., Harimukti, R., \& Jamil, N. A. (2016). Kemampuan Berpikir Tingkat Tinggi Siswa Smp Di Kabupaten Jember Dalam Menyelesaikan Soal Berstandar PISA. Jurnal $\begin{array}{llll}\text { Penelitian Dan Evaluasi Pendidikan, } & 20(2), & \end{array}$ https://doi.org/10.21831/pep.v20i2.8058 
Kustiawan, U. (2016). Pengembangan Media Pembelajaran bagi Anak Usia Dini. Google Books. https:/ / books.google.co.id/books?hl=en\&lr=\&id=gpYqDwAAQBAJ\&oi=fnd\&pg=P

$\mathrm{P} 1 \& \mathrm{dq}=$ pengembangan + media + pembelajaran\&ots $=$ tuNOH_IXEm\&sig $=-$

W6uTXj6RHMSGE3eEq4hogeSjbU\&redir_esc=y\#v=onepage\&q=pengembangan media pembelajaran $\& \mathrm{f}=$ false

Liyana, A., \& Kurniawan, M. (2019). Speaking Pyramid sebagai Media Pembelajaran Kosa Kata Bahasa Inggris Anak Usia 5-6 Tahun. Jurnal Obsesi : Jurnal Pendidikan Anak Usia Dini, 3(1), 225. https:// doi.org/10.31004/obsesi.v3i1.178

Ningrum, E. (2016). Membangun Sinergi Pendidikan Akademik (S1) Dan Pendidikan Profesi Guru (PPG). Jurnal Geografi Gea, 12(2). https:// doi.org/10.17509/gea.v12i2.1783

Nuraeni, L., \& Riyanto, A. (2017). Efektivitas Diklat Berjenjang Tingkat Dasar Terhadap Peningkatan Kompetensi Pedagogik Pendidik PAUD (Studi Deskriptif Pada Pendidik Paud Di Kota Cimahi). P2M STKIP Siliwangi, 4(1), 21. https:// doi.org/10.22460/p2m.v4i1p21-29.388

Nurhafizah, N. (2018). Pelatihan Pembuatan Media Pembelajaran Anak Usia Dini Menggunakan Bahan Sisa. Early Childhood: Jurnal Pendidikan, 2(2b), 44-53. https:/ / doi.org/10.35568/earlychildhood.v2i2b.288

Pangestika, R. R., \& Alfarisa, F. (2015). Pendidikan Profesi Guru (PPG): Strategi Pengembangan Profesionalitas Guru dan Peningkatan Mutu Pendidikan Indonesia. Pendidiakan Profesi Guru (PPG), 4(1995), 671-683. http:/ / eprints.uny.ac.id/21965/1/60 Ratna Rosita Pangestika \%26 Fitri Alfarisa.pdf

Pdspk, I., Statistik, K., Anak, P., \& Dini, U. (2017). Katalog Dalam Terbitan. www.pdsp.kemdikbud.go.id

Prof. Dr. Sudarwan Danim. (2015). Pengembangan Profesi Guru. In Karisma Putra Utama (3rd ed.).

Kencana. https:/ / books.google.co.id/books?hl=en\&lr=\&id=ezq2DwAAQBAJ\&oi=fnd\&pg=PP $1 \& \mathrm{dq}=$ pendidikan+profesi+guru\&ots=ad313Nyv08\&sig=W0xeGj110N4WYEqzxd8bh CTl4Rg\&redir_esc $=\mathrm{y} \# \mathrm{v}=$ onepage $\& \mathrm{q}=$ pendidikan profesi guru\& $\mathrm{f}=$ false

Ries, F. (2016). A Study of Teacher Training in the United States and Europe. The European Journal of Social and Behavioural Sciences, 16(2), 2029-2054. https:// doi.org/10.15405/ejsbs.184

Saurina, N. (2016). Pengembangan Media Pembelajaran Untuk Anak Usia Dini Menggunakan Augmented Reality. Jurnal IPTEK, 20(1), 95. https:/ / doi.org/10.31284/j.iptek.2016.v20i1.27

Sumarsih, S., \& Mukminan, M. (2016). Pengembangan Multimedia Akuntansi Biaya Metode Harga Pokok Pesanan Bagi Mahasiswa Jurusan Pendidikan Akuntansi UNY. Jurnal Inovasi Teknologi Pendidikan, 3(1), 92. https://doi.org/10.21831/tp.v3i1.8266

Usmaedi, U. (2017). Menggagas Pembelajaran HOTS Pada Anak Usia Sekolah Dasar. Jurnal Pendidikan Sekolah Dasar, 3(1), 82. https:/ / doi.org/10.30870/jpsd.v3i1.1040

Widayati, T. (2009). Pengembangan Media Pembelajaran Tutor Paud Dalam Menggali Perilaku Kerjasama Anak Usia Dini Melalui Gerak Dan Lagu. Jiv, 4(2), 113-124. https:/ / doi.org/10.21009/jiv.0402.1

Wolf, S. (2018). Impacts of Pre-Service Training and Coaching on Kindergarten Quality and Student Learning Outcomes in Ghana. Studies in Educational Evaluation, 59, 112-123. https:// doi.org/10.1016/j.stueduc.2018.05.001

Zaini, H., \& Dewi, K. (2017). Pentingnya Media Pembelajaran Untuk Anak Usia Dini. Raudhatul Athfal: Jurnal Pendidikan Islam Anak Usia Dini, 1(1), 81-96. https:// doi.org/10.19109/ra.v1i1.1489 